\title{
DISCURSO DO DR. CELSO LEME
}

Quis a Associação dos Antigos Alunos da Faculdade de Direito de S. Paulo, viesse eu representá-la nas homenagens póstumas, que hoje são prestadas ao professor MaNoEL Pacheco Prates.

A escolha do orador, é preciso que se saiba desde logo, não foi feita pelo critério do mais capaz nem do mais competente; senão pela razão de que melhor poderia falar do velho mestre aquele que melhor o houvesse conhecido.

Eis porque vós deveis ouvir-me. Sêde complacentes! não por mim, mas pelo saudoso professor.

Não vos irei dizer da sua obra jurídica, pois não é esta a missão que me coube. Como aluno que dele fui, talvez mesmo da primeira turma que lhe ouviu as lições - e esta é a razão da minha escolha - cabe-me falar-vos das impressões que nos meios estudantinos deixou gravadas o professor de Direito Civil.

Si assim é, que já nem fale mais eu mesmo! Que nos venha entreter por alguns instantes a saudade, essa moradora eterna do coração humano, que leva a espiar com olhos languidos, durante toda a vida, os bons tempos passados!

Essa dama optimista, que vai esquecendo os momentos de agruras e de aflições para só recordar o que foi bom, o que foi suave, o que foi alegre.

Como amacia a vida o ter saudades!

1912. Começava São Paulo a querer ser uma grande metrópole.

Iam caindo por terra as suas velhas casas coloniais e repontando em seu logar os primeiros arranha-céus. 
Suas ruas estreitas, mal calçadas e poeirentas iam se transformando em largas avenidas, cheias de ar e de luz.

Toda a cidade estremecia sob o incessante trabalho de uma transformação que ainda agora não parou.

Em pleno coração da urbs irriquieta, impassivel como um santo, estava o velho casarão de São Francisco.

Quem o visse de fóra, mal compreenderia o que se passava no seu interior.

Em contraste com os seus vetustos salões e corredores sombrios e dentro de seu pátio enquadrado em arcadas centenárias, uma mocidade despreocupada, alegre e barulhenta recebia, num sonho de grandeza, as mais confortadoras lições de direito e de justiça.

Aprendia que a única fôrça do homem civilizado é a que resulta do direito e rezava, numa prece cívica, um credo diário ao poder imarcessivel da justiça!

Bons tempos!

Entre os mestres, Pacheco Prates. Substituia ele o professor Steidel, na cadeira de Direito Comercial.

Quantas simpatia nos infundia o bom professor!

Mágro, curvado sob uma cabeça toda branca, olhos pequenos, apertados, fechados quasi no esfôrço de vencer, através das grossas lentes dos óculos, uma grande miopia, era pontual em suas áulas.

Quasi sempre fazia-se acompanhar, braços dados, por seu filho ou outra pessoa da familia.

Subia á cátedra, sobre a qual colocava as notas para a preleção e começava.

Sem parar, sem páusa, numa torrente, espunha a matéria, consumindo toda a hora da áula.

Suas palavras coavam-se através dos grandes bigodes brancos, recurvos sobre a bocca, escondendo os lábios.

Não parecia nunca que estivesse falando.

Absorvia-o, por tal forma, a exposição da matéria que não se apercebia, senão de quando em vez, do alarido que 
ia pela sala. Parava, então, de falar, e ficava cabisbáixo, esperando que voltasse o silêncio.

Era a única demonstração de desagrado que lhe ocorria fazer aos seus alunos!

Com que paciência e bondade os recebia sempre!

A todos tratava, com acolhedora intimidade, por "você"

Penso que si algum dia chegou a negar qualquer coisa a seus discípulos, deveria ter sofrido mais do que o que recebera a negativa.

Sua modéstia era tão pronunciada, que muitos, mal o conhecendo, a confundiriam com humildade.

Dir-se-ia querer esconder, nessa aparência simples, todo o tesouro de seu saber e de sua cultura.

Mas não esconder por avareza, por mesquinharia!

Ao contrário disso, ninguem mais generoso em dar do que ele.

Seus pareceres e suas lições eram dádivas que lhe saiam das mãos sempre magnânimas, ao primeiro aceno dos que delas necessitavam.

Passou a vida entre os livros. Estudioso apaixonado do direito, dele e para ele viveu.

Esta circunstância põe um realce de côres luminosas nas solenidades que hoje aqui realizamos.

Honra-se a memória de um cultor das letras juridicas.

Comemora-se o desaparecimento de um varão cujas credenciais únicas são as que lhe outorga o amor sempre manifestado pelo bem e pelo justo.

Nos dias que passam, quando o direito é constrangido a ceder logar á brutalidade da fôrçá; quando a lei vai se fazendo o reflexo da vontade isolada, dos que impunham o poder pela violência, é altamente consolador o espetáculo desta solenidade em honra a um centurião do direito em sua pureza tradicional.

O espirito de escol do grande sacerdote do direito que soube ser sábio e ser bom a um só tempo - ha de neste momento estar pairando sobre este salão. 
Pelo saber e pelo amor ao direito para inspirar e animar a luta sem tréguas contra a teoria da fôrça e da violência que pretende empolgar o mundo.

Realcemos mais. E' uma solenidade que honra aos que a promovem porque, estrême de qualquer interesse material, visa a que já não tem - e nunca teve - mancheias de recompensas para dar em retorno.

Pela bondade e pelo coração para vos pedir, em pról do orador, a mesma indulgência com que julgava os seus maus discípulos. 